\title{
Becoming-Bertha: Virtual Difference and Repetition in Postcolonial 'Writing Back', a Deleuzian Reading of Jean Rhys's Wide Sargasso Sea
}

\author{
Lorna Burns University of Glasgow
}

\begin{abstract}
Critical responses to Wide Sargasso Sea have seized upon Rhys's novel as an exemplary model of writing back. Looking beyond the actual repetitions which recall Brontë's text, I explore Rhys's novel as an expression of virtual difference and becomings that exemplify Deleuze's three syntheses of time. Elaborating the processes of becoming that Deleuze's third synthesis depicts, Antoinette's fate emerges not as a violence against an original identity. Rather, what the reader witnesses is a series of becomings or masks, some of which are validated, some of which are not, and it is in the rejection of certain masks, forcing Antoinette to become-Bertha, that the greatest violence lies.
\end{abstract}

Keywords: Gilles Deleuze, Jean Rhys, writing back, becoming, Wide Sargasso Sea, virtual, Difference and Repetition

Within the postcolonial critic's lexicon, terms such as 'hybridity', 'writing back' and 'creolisation' have come to be associated with a fundamental ambivalence that lies at the heart of the postcolonial project. Indeed, Homi Bhabha's characterisation of the 'location' of the postcolonial moment as a transitory site, 'neither a new horizon, nor a leaving behind of the past' (Bhabha 1994: 1), confirmed radical ambivalence and 'in-betweenness' as the archetypal features of postcolonial resistance: the hybridised subject or creolised text works to undermine colonial authority precisely because it is not easily accommodated into the coloniser's self-assured world-view. In the same way, where postcolonial authors such as Jean Rhys, Derek Walcott, J. M. Coetzee or Aimé Césaire appropriate and rewrite canonical texts, 
writing-back to the imperial canon as Bill Ashcroft, Gareth Griffiths and Helen Tiffin (2002: 96) have argued, it is the production of a text that both does and does not resemble the original work that marks its ambivalent status as a hybrid or creolised text. Yet, what has remained understated in contemporary postcolonial criticism is the extent to which both hybridity and creolisation do witness the birth of 'a new horizon'. Rather than locating the revisionary potential of postcolonial aesthetics within an ambivalent hybridity, I contend that it is the overlooked ability to effect the new that distinguishes postcolonial discourse and, crucially, marks its compatibility with the philosophical writings of Gilles Deleuze. Elaborating the distinction that Deleuze in Difference and Repetition identifies between the first and third syntheses of time, this essay outlines a Deleuzian approach to postcolonial writing back by drawing on the particular example of Jean Rhys's Wide Sargasso Sea and identifying the repetitions of virtual difference and becomings that make Rhys's canonical re-dress a genuinely original literary expression.

At issue in this essay is not simply the question of whether Rhys's novel, or any example of postcolonial writing back, is a new work of literature, but rather, at a more fundamental level, a question of the particular relationship between the postcolonial present and the colonial past enacted in writing back. Indeed, this question is evident in Bhabha's own formulation of the postcolonial moment as neither a 'new horizon' nor the abandonment of historical memory. Despite this suggestion, The Location of Culture does not oppose the idea of the postcolonial as the production of the new: Bhabha later defines cultural translation as "an encounter with "newness" that is not part of the continuum of past and present' (Bhabha 1994: 7), and argues that the hybrid object be recognised as 'new, neither one nor the other' (25). However, it is the concern to define postcolonialism as both the liberation of the subject from the traumatic legacies of colonialism and the care that the past be not forgotten that leads Bhabha to ostensibly reject the horizon of the new. In turn, what is needed to address this concern is an understanding of postcolonialism as a historical relation that gives rise to a newness 'that is not part of the continuum of past and present', but which is, nevertheless, derived from a particular (colonial) history. It is this paradoxical relation in which the engagement with history both generates a future with the potential to become something wholly new and revises our understanding of all that led up to it (a new continuum that leads from past to present and into the future) that Deleuze establishes in his third synthesis of time: articulating a theory of becoming that accounts for the production of the new from a 
re-dress of the past and, I argue, when applied to writing back, reveals the revisionary force of postcolonial writing.

The significance of Deleuze's philosophy for postcolonial studies has received little attention to date, with Peter Hallward's Absolutely Postcolonial remaining the most comprehensive critique of Deleuze's influence on the field. For Hallward, questions of singularity, specificity and, crucially, locatedness take centre stage in his attack on a Deleuzian postcolonial discourse, arguing that while colonial and counter-colonial discourse may indeed be criticised for their over-specification of the subject, in his view, the postcolonial has moved in precisely the opposite direction, towards a singular reality which 'will operate without criteria external to its operation'; replacing 'the interpretation or representation of reality with an immanent participation in its production or creation: in the end, at the limit of "absolute postcoloniality", there will be nothing left, nothing outside itself, to which it could be specific' (Hallward 2001: xii). Implicit in Hallward's argument is the view that postcolonialism tends to follow a logic of immanence or singlesubstance (Burns 2009: 104-5). As such, everything exists as a particular element within the singular substance that we might term the universe, and is nothing other than a particular configuration of that singlesubstance. Accordingly, for Hallward, the postcolonial will tend towards the elimination of specific histories, locations or cultures as independent, contextualising forces and, as a result, postcolonial discourse can be regarded as 'more or less enthusiastically committed to an explicitly deterritorialising discourse in something close to the Deleuzian sense - a discourse so fragmented, so hybrid, as to deny its constituent elements any sustainable specificity at all' (Hallward 2001: 22).

While Hallward's work does represent a significant and distinct intervention in the field of postcolonial studies, the core logic behind his critique should sound familiar since it echoes precisely the criticism that Hegel levelled against Spinoza's notion of singularity. To recall Hegel's indictment of Spinoza in his Lectures on the History of Philosophy, 'the cause of his [Spinoza's] death was consumption, from which he had long been a sufferer; this was in harmony with his system of philosophy, according to which all particularity and individuality pass away in the one substance' (cited in Hardt 1993: 257). For Hegel, as for Hallward, the Spinozist conception of substance and positive (or immanent) differentiation cannot provide a basis for particularity or the specific since it lacks the core feature of determination: dialectical negation. As Michael Hardt argues, 'according to Hegel, the unique and absolute being of Spinozism cannot provide a basis for determination 
or difference because it involves no other or limitation' (Hardt 1993: 67). Within a Hegelian ontology, determinate or specific being emerges through the negation of its opposite, nothingness, and it is this opposition between being and nothingness that 'defines the foundation of real differences and qualities' (Hardt 1993: 3). In other words, difference is always produced through a negative movement and each thing exists in its particularity and difference through the active negation of something else. Importantly, this view of difference is echoed in Absolutely Postcolonial in which Hallward highlights what he considers to be effective acts of postcolonial resistance, such as the fiction of V. S. Naipaul, in which difference emerges when 'Naipaul puts himself and his characters in a position of judgement, as alternatively judge and judged' (Hallward 2001: 332). As a result, Naipaul's work 'is simply specific rather than singular, inflected through the experience of a positioned narrator or character and maintained as a network of [...] relationships' (332). In other words, for Hallward difference and specificity are produced negatively through one's situated opposition to an other.

Hallward's claim that the lack of situated opposition or determination in postcolonial literature results in a discourse that, given the absence of negation, cannot sustain real difference and will inevitably dissolve into an undifferentiated nothingness must be recognised for what it is: a contemporary elaboration of Hegel's critique of Spinoza's positive ontology. As such, Hallward's argument faces strong criticism from the philosopher he holds responsible for the singularising nature of postcolonialism: Deleuze. Hardt has shown in detail how Deleuze draws on both Spinoza and, in particular, Bergson to demonstrate that negative determination not only presents a false notion of difference but also, controversially from Hallward's point of view, 'fails to grasp the concreteness and specificity of real being' (Hardt 1993: 4). Put simply, Deleuze elaborates both Bergson and Spinoza to argue that Hegel's concept of negative or dialectical differentiation cannot provide an adequate foundation for being since it depends on external causes, thus introducing contingency and causality into being: to quote Deleuze, 'in Bergson $[\ldots]$ the thing differs with itself first, immediately. According to Hegel, the thing differs with itself because it differs first of all with all it is not' (cited in Hardt 1993: 7). Hallward's reluctance to fully acknowledge the Hegelian logic behind Absolutely Postcolonial results in an argument against postcoloniality and Deleuze that fails to address Deleuze's own ready-made answer to the charge of singularity as well as postcolonial criticism's demand to face the emergence of newness and not just specific instances of located resistance. As a result, his reading rests upon a 
critique of differentiation at odds with Deleuze's commitment to an immanentist philosophy. However, by recognising the value of positive differentiation and the shift away from dialectical negation as the foundation of being, a more significant form of postcolonialism emerges based on instances of virtual difference, repetition and becoming-new. ${ }^{1}$

It is this aspect of Deleuze's philosophy that Caribbean writers such as Édouard Glissant and Wilson Harris draw on in their own postcolonial works. Notably, both Glissant and Harris envision the postcolonial project as an engagement with the traumatic history of colonialism that, nevertheless, creates a new, unpredictable future: a 'prophetic vision of the past' (Glissant 1999: 64), for Glissant or in Harris's characteristically opaque prose, 'continuities running out of the mystery of the past into the unknown future yield proportions of originality, proportions of the "genuinely new"' (Harris 1996: 6). The particular engagement with history that both Harris and Glissant propose in their writings represents a shift from what Walcott designated a literature of 'recrimination and despair' (Walcott 1998: 37) which endlessly repeats the biases of colonialism, towards a revisionary postcolonial literature. Wole Soyinka's denunciation of the negritude movement as that which trapped 'itself in what was primarily a defensive role' (Soyinka 1976: 129) and 'stayed within a pre-set system of Eurocentric intellectual analysis both of man and society and tried to re-define the African and his society in those externalised terms' (136) highlights the point of contention: counter-colonial discourse is wholly specified by the colonial context in which it exists, it adheres to the 'pre-set system' in which the black man is cast as the racial other. The postcolonial, on the other hand, while drawn from a particular socio-historic milieu (one marked by the traces of the colonial era), is distinguished by its ability to move beyond the 'defensive role' of counter-colonialism. It is a discourse that exceeds the already established, 'pre-set' value systems that Europe imposed on its colonial others. In other words, postcoloniality denotes a synthesis of the past that does not repeat predetermined attitudes, but creates something new: an original future not determined at the outset by pre-existing socio-historic subject positions or cultural hierarchies, but, nevertheless, specific to those legacies.

\section{Expectancy, Stereotypes and the First Synthesis of Time}

The distinction that I am arguing for between a historical relation that repeats already established biases and fixed subject-positions and a postcolonial re-dress of history that engenders the absolutely new is 
clarified by Deleuze's account of the first and third syntheses of time. As Deleuze presents it in Difference and Repetition, the first synthesis of time is a theoretical paradigm that accounts for the continuation of the same and the general. Crucially in terms of the particular relationship to the canon that is enacted in writing back or what Edward Said designates 'contrapuntal' reading (Said 1993: 59), for Deleuze the first synthesis is the creation of expectancy through repetition, accounting for the way in which, in the present, we come to anticipate future events because of their past occurrence. For example, the repetition in the series $A B$, $\mathrm{AB}, \mathrm{AB}, \mathrm{A} . .$. , Deleuze argues, 'changes nothing in the object or state of affairs $\mathrm{AB}$. On the other hand, a change is produced in the mind which contemplates: a difference, something new in the mind. Whenever A appears, I expect the appearance of B' (Deleuze 2004: 90). In this 'contraction' of specific instances of ' $\mathrm{A}$ ' and 'B' into 'AB', the first synthesis of time produces a movement from the specific to the general (91). Furthermore, the effect of this contraction is to create a sense of expectancy: in this case, the recurring experience of $\mathrm{A}$ followed by $\mathrm{B}$ is contracted in the present into the projected expectancy that $A B$ will recur in the future.

It is this sense of expectancy that underlies postcolonial authors' problematic relationship with the canon and historical legacies. Following Ashcroft et al., the relationship envisioned here is not between individual authors or works since the 'canon is not a body of texts per se, but rather a set of reading practices (the enactment of innumerable individual and community assumptions, for example about genre, about literature, and even about writing)' (Ashcroft et al. 2002: 186). In writing back, postcolonial authors seek to expose not only specific prejudices, expressed in particular cases, but the continuing influence of these views. In Emily Brontë's Wuthering Heights, for example, the reader encounters particular references to the colonies and racial others, expressed in a particular way. One might then read Charlotte Brontë's Jane Eyre and register a repetition in the way in which both authors depict the relationship between the coloniser and the colonised, a repetition that is echoed as one then reads Austen, Dickens and so forth. It is the repetition of these specific ways of characterising the relationship between centre and periphery that is contracted into what might be termed, in general, as a colonial attitude. Importantly, as Deleuze's account of the first synthesis emphasises, it is not a change in the texts themselves or in that which is repeated, but it is a change in the mind of the reader who registers the repetition. This is why the canon evokes reading practices: the repetition of themes, attitudes or genres in 
specific texts are synthesised in the mind to create a general expectancy, a general set of reading practices that will, accordingly, shape future reading experiences. As the process which engenders this expectancy, the first synthesis is that which makes of the canon a set of reading practices that determines in advance one's response to the text.

It is this expectancy that writers such as Rhys seek to challenge as they produce works which ostensibly repeat canonical texts. Wide Sargasso Sea as a whole, and in particular Part Three of the novel, is a repetition of Brontë's Jane Eyre. However, it is a repetition that exposes the processes of contraction and projection that Deleuze's first synthesis envisions by deconstructing colonial stereotypes and demonstrating, as Albert Memmi argued, that in colonialist discourse what 'is actually a sociological point becomes labelled as being biological or, preferably, metaphysical' (Memmi 1974: 71-2). Thus, in Part One of Wide Sargasso Sea, Mr Mason's complaint that the recently manumitted black Jamaicans 'won't work [...] don't want to work' (Rhys 2000: 30) is re-read by Rhys within the specific historical context of Jamaica in the wake of Emancipation and the end of the Apprenticeship scheme. As a result, $\mathrm{Mr}$ Mason's statement is revealed as a contraction of a number of converging sociological features of Jamaican society at that time into a general 'truth' about the newly manumitted population. A similar prejudice is articulated by Rochester during the couple's honeymoon at Granbois when he criticises Christophine's 'horrible' language as she asks him to 'taste my bull's blood, master' (71), her trailing dress and her languorous appearance. Here Rochester expresses the coloniser's point of view: the black woman, he infers, is unclean, sexualised and lazy. All colonial stereotypes, yet in each case, Antoinette responds by telling Rochester that each of these traits have a logical explanation: allowing one's dress to get dirty is an expression of affluence, slow movements are about precision. The difference between the two characters' perception of Christophine's actions is that Rochester reads in them a confirmation of colonial stereotypes as inherent or biological truths about black women, whereas Antoinette understands them as sociological points.

Rhys's novel consistently undermines stereotypes by illustrating their constructed, sociological basis. However, more than this, Wide Sargasso Sea draws attention to the additional issue of expectancy that is created: the specific repeating trait drawn from the past is generalised to form some 'truth' about the present and, as Deleuze points out, determines the way in which future repetitions are perceived. In Rochester's changing relationship with his wife, the full force of Rhys's critique of expectancy is felt. Throughout Part Two of the novel, Rochester 
is clearly involved in a process of, to paraphrase Sartre, making Antoinette like what she would have to be like to deserve her fate (her eventual incarceration in the attic of Thornfield Hall as the mad, violent Bertha). ${ }^{2}$ Rochester does this in the most matter of fact way: literally renaming her Bertha. More than this, however, he exploits prevalent stereotypes about white creoles in order to reread Antoinette's actions as a sign of her sexual proclivity and inherited madness. In this way, Antoinette's white dress, once admired by Rochester, comes to reflect his expectations of his wife's disposition. The dress that 'had slipped untidily over one shoulder and seemed too large for her' (105), as Carine Mardorossian argues, evokes association with '(black) female sexual wantonness and prostitution' (Mardorossian 1999: 1076), suggesting an intentional provocation on Antoinette's part and recalling Rochester's earlier claim that 'one afternoon the sight of a dress which she'd left lying on her bedroom floor made me breathless and savage with desire' (78). While this latter quotation evidences his sexual desire, Rochester's narrative increasingly seeks to read Antoinette's actions as a sign of her unrestrained sexuality. Thus, the dress that was, perhaps, carelessly left lying on the floor is misconstrued as a purposeful incitement to Rochester's desires. Antoinette's misunderstood intentions are underscored by the parallel image of the Miller's Daughter that occurs earlier in the text: one evening at Coulibri Antoinette recalls her "favourite picture "The Miller's Daughter", a lovely English girl with brown curls and blue eyes and a dress slipping off her shoulders' (30, emphasis mine). ${ }^{3}$ Antoinette's later mirroring of this image is, therefore, a misunderstood attempt to conform to Rochester's cultural values, to project an image of what, to her limited understanding, 'a lovely English girl' should look like.

It is, however, after his meeting with Daniel Cosway, the illegitimate son of Antoinette's father and a black slave, that Rochester's wilful misinterpretation of his wife's character becomes most apparent. Daniel's vindictive assertion that 'Mrs Cosway is worthless and spoilt, she can't lift a hand for herself and soon the madness that is in her, and in all these white Creoles, comes out' (80) re-enforces the prevalent stereotype that madness afflicts the white creole plantocracy. However, although Daniel's venom is clearly directed against the exslave-owners (he does not single out madness as Antoinette's or even Annette's affliction, but rather as the fate of 'all these white Creoles' (Mardorossian 1999: 1082)), Rochester recalls only that which confirms his misgivings about his wife. Echoing Daniel's parting words, 'give my love to your wife - my sister. [...] You are not the first to kiss her pretty 
face' (104), the final pages of Rochester's narrative refigure Daniel's accusation as an admission of incest: 'give my sister your wife a kiss from me. Love her as I did - oh yes I did' (130). Rochester's firm resolution to secure his wife and her fortune by returning to his English estate is revealed as the product of his distorted recollection of Daniel's words and the confirmation of his own pre-determined expectations about creole, female sexuality: 'she thirsts for anyone - not for me [...] (a mad girl. She'll not care who she's loving). She'll moan and cry and give herself as no sane woman would - or could. Or could' (135-6). Faced with the discrepancy between Antoinette and the portrait of the lovely English girl' she tries to mimic, here Rochester resolves to make of his wife the very opposite image of female sexuality and, just as he names her Bertha, here he names her mad by giving her a sexual proclivity that 'no sane woman would' have. In his final resolution to 'see who hates best' (140), Rochester reveals the extent to which fears about miscegenation and the licentiousness of white creoles in nineteenth-century colonialist discourse created a projected expectancy about creole behaviour: a preestablished framework that determines Antoinette's actions from the outset of the novel.

Rhys consistently confronts colonial stereotypes not purely as a means to suggest that, in agreement with Memmi, that which is misconstrued as a biological or metaphysical fact is, in truth, socially or culturally determined, but also in order to expose the force of expectancy. It is, in particular, the issue of canonical expectancy, created by the texts of the past in the mind of the reader and projected into the future as a set of regulatory reading practices, that underlies the postcolonial tradition of writing back. In enacting a contrapuntal rewriting, authors expose the ideological biases that lie behind certain generalised expectations: highlighting the syntheses that occurred in order to produce particular stereotypes or reading practices, while at the same time revealing what was excluded by such generalisations. Rhys's text is exemplary in this respect: returning her text to the historical moment of Emancipation in the Anglophone Caribbean to expose the formation of colonial stereotypes and prejudices, and to highlight the social factors that were excluded from accounts of creole madness such as she found in Brontë's novel. By deconstructing colonial stereotypes, Rhys's novel challenges preconceived attitudes by returning the general to the specific. Writing back, therefore, works by confronting expectancy and what we might term a contrapuntal rereading/rewriting, in line with Deleuze's first synthesis of time, directs its attention to the contraction of the specific past into a generalised framework for determining the future. 
In turn, this is exemplary of the distinction between counter-colonial discourse and the postcolonial previously delineated: by writing against the expectancy created by the first synthesis of time, Caribbean writers do not envision the continuation of a fixed relationship between centre and periphery, but engender an unpredictable future specific to but not limited by the contracted past. In other words, postcolonial texts must reject the determination of the Deleuzian first synthesis as a contraction of the past that has created the generalised colonial relationship and propose a new continuum. This latter process Deleuze calls the third synthesis of time: a differentiation of the past as a virtual presence in the production of an unpredictable future. It is only through an analysis of the ways in which Rhys contrapuntally exposes the virtual past she encounters in Brontë's novel and depicts the singular conditions by which Antoinette becomes Bertha that we can appreciate the full force of Rhys's re-dress and uncover the processes of virtual repetition and becoming-new that characterise a truly postcolonial aesthetics of writing back.

\section{Becoming-Bertha}

Far from remaining ambivalent to the role of past trauma in shaping the postcolonial present, writers such as Rhys, Harris and Glissant recognise history as formative, but see in trauma and oppression a potentiality to re-dress historical antagonisms and create something new. Indeed, it is this appreciation of a historical relation that effects the 'genuinely new' that Harris locates in Rhys's novel (Harris 1996: 6). Relating Wide Sargasso Sea to a template of war he finds in the history of the Caribs and Arawaks, Harris uncovers in the mythology of opposing cultures, common, repeating features that speak of a single source of collective creativity:

it is a time of war. The rainbow compression of a tree is set on fire by the Caribs when the Arawaks seek refuge in its branches. [...] Creation suffers and needs to be re-dressed if the spirit of the stars is to be discovered again. The fire rages and ascends even higher to drive the Arawaks up and up until there is no further escape, they burn and rise into a spark in the sky of fiction. That spark becomes the seed of the garden of the Pleiades. (Harris 1983: 50)

For Harris, the memory of past conflict retains a virtual aspect, a 'seed', which remains latent in the collective unconscious, ready to be recalled and explored in order to creatively re-dress historical trauma. What Harris finds in Rhys's novel is the potential for a future that is not a 
repetition of historical antagonisms and conflicts, but one which 'yields proportions of originality' (Harris 1996: 6) through a re-dress of the past. As Harris argues in his own novel Jonestown, it is essential to create a jigsaw in which "pasts" and "presents" and likely or unlikely "futures" are the pieces that multitudes in the self employ in order to bridge chasms in historical memory' (Harris 1996: 5). What Harris refers to as the 'incalculable' (5) line of continuity between the past and an unpredictable future emerges in the postcolonial project as a form of restructuring by which genuine novelty or 'newness' results.

It is in this respect that Deleuze emerges as an important figure in this debate and, in particular, his reformulation of a Spinozist plane of immanence or single-substance philosophy. Where Spinoza recast the Cartesian separation of Thought and Extension as an immanentist philosophy in which the single-substance universe (God or Nature) is conceived under two attributes termed natura naturans and natura naturata, a (virtual) self-creating aspect and the structure of (actual) created things respectively, Deleuze adopts Spinoza's dual sense of actual created world and virtual creative force as the two 'unequal odd halves' of reality (Deleuze 2004: 261). ${ }^{4}$ Like Spinoza, Deleuze argues that reality must be considered both as the actual world and, at the same time, as a virtual plane which exists in opposition to the actual. Crucially, while the Cartesian split ensured that Thought and Extension persisted as nonrelational, distinct spheres, Spinoza's single-substance ontology offers a relational structure that is reflected in the way in which Deleuze presents the actual and the virtual as caught up in a ceaseless movement from one to the other; where elements of the virtual become realised within the actual, experienced as sensations, events or identities. Where Deleuze exceeds Spinoza is in the profound creativity that he locates within this movement from virtual to actual. Rather, it is to another philosopher, Henri Bergson, that Deleuze turns to find a theory of the virtual as both a creative force (what Bergson terms élan vital) and a historical relation that, to recall Harris, 'yields proportions of originality, proportions of the "genuinely new"' (Harris 1996: 6).

It is the virtual's status as the absolutely-other, as that which cannot be represented since by definition it is that which exceeds the limits of the actual, that ensures its role in maintaining the renewed potential for newness. As Daniel Smith explains, because 'the virtual is constituted through and through by difference $[. .$.$] when it is actualised, it therefore$ differs from itself, such that every process of actualisation is, by its very nature, the production of the new' (Smith 2007: 6). Thus, any actualisation of the virtual is essentially a creative process since what 
emerges will be different from that which already exists within the actual. Crucially, it is this movement from virtual to actual (what Deleuze terms 'differentiation') that Bergson introduces in his notion of élan vital, understood as 'a virtuality in the process of being actualised' (Deleuze 1991: 94). With this concept, a full sense of the relation between actual and virtual comes into focus and, moreover, offers a philosophical paradigm for change and novelty. Since each actualisation of the virtual designates the emergence of the new, both élan vital and differentiation describe the creative evolution of the immanent totality: 'evolution takes place from the virtual to actuals. Evolution is actualisation, actualisation is creation' (Deleuze 1991: 98).

Differentiation accounts for the ways in which newness enters the world; however, more than this, Bergson's sense of the virtual as a 'gigantic memory' (Deleuze 1991: 100) ensures that this creative process is also a temporal evolution. The past for both Deleuze and Bergson is a virtual field that is available for differentiation within the present as recollection. At issue here is not history since the past as virtual has 'no psychological existence', it is 'not a particular past of a particular present but [...] is like an ontological element, a past that is eternal and for all time, the condition of the "passage" of every particular present. It is the past in general that makes possible all pasts' (Deleuze 1991: 56-7). By constituting that which enables each present to pass and 'preserve itself in itself' (58), the pure or general past (what Deleuze in Difference and Repetition terms the second synthesis of time) represents what James Williams describes as a virtual 'archive' in which 'all events, including those that have sunk without trace, are stored and remembered as their passing away, independent of human activity and the limitations of physical records' (Williams 2003: 93, 94). ${ }^{5}$ Clearly, the premise of a pure past independent of physical records or active recollection is of great significance to Caribbean writers and theorists faced with a historical inheritance of 'amnesia' (Walcott 1998: 39-40). As Jean Bernabé, Patrick Chamoiseau and Raphaël Confiant write in their manifesto of créolité, 'our history (or our histories) is not totally accessible to historians. Their methodology restricts them to the sole-colonial chronicle. Our chronicle is behind the dates, behind the known' (Bernabé et al. 1993: 99). Precisely by accessing that which lies 'behind the known', a postcolonial synthesis of the past repeats the processes of actualisation that Deleuze locates in Bergson's theory of memory as virtual presence. Further, as a differentiation of the virtual what emerges from this process is new, a wholly novel postcolonial 'chronicle'. 
Deleuze's account of the relational movement of the actual and virtual as a temporal, creative evolution in Bergsonism echoes his elaboration of the three syntheses of time in Difference and Repetition. While the past as virtual implies that any differentiation of the past will result in the production of the new, the first synthesis gives consistency to the present by relating it to a distinct series $(\mathrm{AB}, \mathrm{AB} \ldots)$ of the pure past and then subjecting it to the processes of contraction and generalisation. In this way, the newness that is created via differentiation is assimilated by habit and generalised as anticipated behaviour towards the future. The first synthesis alone cannot account for the radical sense of the future as an infinite potentiality that is evident in the writings of Harris and Glissant. As a result, this demand to account for a future with the ability to become-new leads us beyond the first and second syntheses of time 'in the direction of a third' (Deleuze 2004: 111).

With the third synthesis of time Deleuze offers a full account of how newness enters the world. Where the first synthesis demonstrates the way in which actual things gain consistency in the present and the second synthesis details a pure past into which each present falls, the third synthesis accounts for the prevailing sense that the future maintains the potential to become something wholly new. In other words, what I have presented here as differentiation, the actualisation of the virtual, Deleuze names the third synthesis of time: a theoretical paradigm that accounts for the infinite ways in which the actualised present retains the ability to become in unpredictable ways. Further, as a differentiation of the pure or virtual past, Deleuze's third synthesis may be used to elaborate Said's claim that contrapuntal reading uncovers that which was excluded from the colonial text. In other words, when Said argues that we should re-examine Jane Eyre to discover the latent prejudices within the text, he is asking us to differentiate Brontë's work, exposing the unspoken assumptions and unacknowledged exploitations that are taken for granted within the economy of the nineteenth-century novel. In turn, what this contrapuntal reading engenders, according to the Deleuzian model, is new. By actualising the virtual (here the virtual 'side' of the canonical text), the repetition on which the third synthesis is based is not, as in the first, grounded on recurring instances of the contracted past, but on the repetition of the virtual past's becomingactual, of differentiation as the production of the new (what Deleuze designates the eternal return of difference-in-itself). In turn, writing back produces an original work of literature not because it repeats the actual text or canon that has generated certain generalised expectations and reading practices, but because in actualising the virtual aspect of the 
canon it repeats only the processes of differentiation necessarily as a becoming-new.

The same holds true of Rhys's contrapuntal reading of stereotypes in Wide Sargasso Sea, in which her account of the ways in which these stereotypes become established reveals the specific socio-economic factors that were excluded from the generalised form. What Rhys's novel repeats then is not the actual colonial stereotype per se, but the processes of becoming that engendered those contractions. In the same way, by contrapuntally rewriting Jane Eyre, Rhys's novel does not repeat the actual elements of Brontë's work, but, more specifically, the processes of becoming that constitute it: Antoinette's becoming-mad; Rochester's becoming-cold-hearted. Moreover, as with all becomings, according to the Deleuzian model, the movement from virtual to actual that the third synthesis encapsulates does not exhaust the virtual: the virtual is not actualised outright. Rather, a virtual aspect is differentiated with each becoming and each actual state that one becomes maintains, in excess of its actuality, its virtual aspect: 'every object is double without it being the case that the two halves resemble one another, one being a virtual image the other an actual image' (Deleuze 2004: 261). It is this renewed virtuality that accounts for the prevailing sense that things always have the potential to become-new: as Claire Colebrook argues, 'each actual thing maintains its own virtual power. What something is (actually) is also its power to become (virtually)' and that this virtual difference is 'the power to become in unforeseen ways, always more than this actual world, and not limited by its already present forms' (Colebrook 2002: 96). As a result, with each repetition (of stereotype, of text) in Rhys's novel, not only do we see how things became what they actually are, but remain aware of how very different they might have been and, indeed, might yet become. It is this potentiality to become in unforeseen ways that the third synthesis as differentiation evokes. Accordingly, with each actualisation of Bertha (Antoinette's becoming-mad, becoming-violent), Rhys highlights how things might have been or might yet become very different. Rochester's moment of hesitation, 'I shall never understand why, suddenly, bewilderingly, I was certain that everything I had imagined to be truth was false. False. Only the magic and the dream are true - all the rest's a lie. Let it go' (138), Christophine's offer to care for Antoinette, and Rhys's famously open ending, these alternative paths all suggest lines of becoming that remain virtual, engendering the possibility that in every repetition of becoming-Bertha, becoming-Rochester things could have been different. It is this virtual aspect of becoming that destabilises the expectancy of the first synthesis of time and ensures that 
the historical re-dress enacted in postcolonial writing back repeats only the revisionary potential of differentiation as the production of the new.

This is why, to use Colebrook's phrase, becoming is 'the hidden force of difference' (Colebrook 2002: 120): it designates the actualisation of different virtual intensities as a becoming-new and conceives of difference independently of the forms of representation which reduce it to the Same, and the relation of different to different independently of those forms which make them pass through the negative' (Deleuze 2004: xvii-xviii). Deleuze rejects the Hegelian formula of difference whereby any object (salt, say) is differentiated negatively via its oppositional relation to its other (pepper). Rather, for Deleuze difference is an expression of becoming, so that, to extend the example, salt is different to other sensations as an actualised intensity of becoming-salty, becoming-crystallised. As Williams explains, 'according to Deleuze you are not different from other humans because you differ in this or that actual characteristic but because your thoughts and sensations, the way you change, express a different relation of intensities' (Williams 2003: 9). Thus, if we look to Wide Sargasso Sea and find that Antoinette is different to Brontë's Bertha, it is not in actual characteristics that the significant difference lies, but in Antoinette's actualisation of different degrees of becoming-mad, becoming-licentious. What we recognise in Rhys's novel is a different process of becoming at work: Antoinette does not become mad because of some inherited disposition to do so, but because of a range of emotional, social and gender-specific forces acting upon her. This is the very definition of what Deleuze calls a minor literature: repeating not the actual elements of the canon, but the virtual becomings as that which makes things differ. Texts like Wide Sargasso Sea, Colebrook argues, repeat 'the hidden forces of difference that produce texts, rather than repeating the known texts themselves' (Colebrook 2002: 120); or again, 'a work of literature is not to copy that work, but to repeat the forces of difference that produced that work [...]: a repetition of the virtual and hidden power of difference' (121). ${ }^{6}$

Wide Sargasso Sea in a very clear way draws from the virtual side of Jane Eyre. As Rhys herself claimed, responding to Brontë's depiction of 'the poor Creole lunatic', 'that's only one side - the English side' (cited in Raiskin 1996: 133). Bringing to light the other side of the story, detailing Bertha's West Indian upbringing, tracing the disillusionment of Rochester, taking her reader behind the closed doors of Thornfield Hall, Rhys contrapuntally differentiates Jane Eyre. In doing so, what is produced is not a continuation of the same (this would be a result of the first synthesis), but an original work 
through the repetition of the processes of differentiation: 'repetition is never a historical fact, but rather the historical condition under which something new is effectively produced' (Deleuze 2004: 113). Further, by accounting for an engagement with the past that creates a new vision of the future, Deleuze's third synthesis can be used to expose the full significance of Harris's reading of Wide Sargasso Sea. The fire motif that runs throughout the novel, signifying both destruction (the burning of Coulibri) and resistance (Antoinette's fire-red dress which symbolises her revolt against her husband and foreshadows her expected burning of his estate house), speaks to Harris of Rhys's attempt to re-dress absolutes and 'the paradox of resources of variables of the imagination through which the past speaks to the present and to the future [...], its inner capacity for re-dressed bodies and imageries' (Harris 1983: 61). What Harris envisions is a return to the memory or mythology of past conflicts in order to uncover unconscious (virtual) dimensions which may be synthesised in such a way as to allow the past to 'speak' to the present and future in a new way. Indeed, Deleuze envisions this too: the third synthesis, he tells us, marks a break or 'caesura' in the contemporary ordering of time and witnesses the birth of a new order of 'the before and the after' (Deleuze 2004: 112). The third synthesis is not a rejection of the past and although it incites a future that is radically different from what has come before, it is a future that is both linked to the past and which, to evoke Bhabha, generates a new continuum that leads from past to present and future.

Where Harris and Deleuze ostensibly disagree is in Harris's claim that Rhys's re-dress of historical antagonisms in Wide Sargasso Sea works through the identification of what he calls a 'core of likeness' (Harris 1983: 56). This point emerges in his discussion of the Arawaks and Caribs whose adverse relationship, he argues, might be addressed by the realisation of a common creative thread. In the same vein, Harris finds in Rhys's 're-dress of Charlotte Brontë's polarisations', a similar trajectory in which 'a cross-cultural web and likeness are revealed [...] through points that unravel apparently incompatible appearances' (56). It is in the exposure of 'likeness[es]' in apparent polarisations that Harris locates the potential for historical re-dress, a move that ostensibly sets him in opposition to Deleuze's celebration of difference and becoming. However, Harris's evocation of likeness is not to be misunderstood as signifying the same: the same is the foundation of the 'narrow basis of realism [... which] tends inevitably to polarise cultures or to reinforce eclipses of otherness within legacies of conquest that rule the world' (55). Realism is a reflection of the same and, accordingly, creates 
the polarisations Harris seeks to overcome. Likeness, therefore, is not equivalent to the same: as Harris argues,

the politics of culture assume that like to like signifies a monolithic cradle or monolithic origin. Whereas in creative subtlety or re-dress $[\ldots]$ monoliths are extremes/extremities that become fissures of emotion in claustrophobic and historical or cultural space, when imbued with asymmetric spirit or intangible, untameable life. Those fissures are parallels, extensions [...] in and into bodies of experience whose mental point or core of likeness turns into the spark or passion of science and art. (Harris 1983: 56)

What Harris refers to as a 'core of likeness' is not the identification of the same, but what he senses in the cross-cultural web: a single, collective unconscious that links all peoples and ties all cultures to a common creative 'spark'. Put another way, what Harris finds revolutionary is the virtual presence of the past as an undifferentiated (virtual) whole, to frame this in Deleuze's terms, as that which gives all the ability to become in unforeseen ways.

Harris's presentation of the past or collective unconscious as a virtual archive into which each present passes is fundamentally aligned with the Deleuzian/Bergsonian sense of creative evolution and memory. Paradoxically, although Harris identifies a 'core of likeness' at the heart of historical re-dress, it is fundamentally an issue of what Deleuze terms difference: a repetition of the virtual past's becoming-actual as that which engenders a new ordering of history. In particular, Harris invokes a Deleuzian concept of difference-in-itself rather than the Hegelian dialectic by arguing for the recognition of 'ceaseless parallel animations or subtle likeness through contrasting densities or opposite and varied appearances' (56). In other words, what is taken for granted as a difference achieved through opposition is, in fact, a difference of degrees of becoming, of 'densities' or 'appearances'. That Harris employs the term 'likeness' rather than Deleuze's difference-in-itself is a sign of the emphasis that Harris wants to place on the immanent creativity of the virtual as that from which differences are actualised or becomeactual. To the extent that all identities are particular configurations or expressions of differentiated becomings emerging from the infinite virtual aspect of a single, immanent reality, all apparent adversaries are 'like' one another in that they all actualise the virtual albeit in different ways. Thus, Harris notes, despite their polarisation in Jane Eyre, 'Bertha and Rochester possess in themselves, within the genius of Charlotte Brontë, the seeds of such re-dress' (61). Brontë's characters always had the potential to overcome historical antagonisms, the ability to become 
in unforeseen ways. If the 'seminal force of the fiction of the whole' (61), Brontë's commitment to the structuring influence of tradition and ideology, meant that this potential remained virtual in Jane Eyre, in Rhys's novel the repetition of becoming rather than the actual aspects of Brontë's text realises the potential for re-dress in the production of a new work of (minor) literature.

Through the repetition of Jane Eyre in Wide Sargasso Sea the reader encounters not an accumulation of actual differences, but differencein-itself: the expression of becomings that emerge in particular ways relative to a range of other becomings. The actual differences between Jane Eyre and Wide Sargasso Sea - the discrepancy of names ('Bertha is not my name' [121]); of dates (the timeframe of Jane Eyre is 1789-1808, while Wide Sargasso Sea is set slightly later, roughly 1834-44); of mother's name (Bertha's mother's name is Antoinetta, not, as in Wide Sargasso Sea, Annette); of family lineage (there is no Cosway line in Jane Eyre) - these actual discrepancies alone diminish full the significance of Rhys's novel by setting up an oppositional framework in which Wide Sargasso Sea is measured against the gold standard of the original parent text, Jane Eyre. ${ }^{7}$ On the other hand, by acknowledging the virtual repetitions in Wide Sargasso Sea a more significant difference is uncovered, one which does not function through negation but as an experience of becoming expressed in relation to other becomings or intensities such as Emancipation, creole society and colonial attitudes. Features of Rhys's novel such as the changes in Antoinette's name from Antoinette Cosway to Mason and finally Rochester, her husband's renaming of her as Bertha, Christophine's affectionate but childlike names for her, and Daniel's reference to her as Antoinetta (the middle name of Brontë's Bertha and her mother's name in Jane Eyre) should not be misunderstood as a form of violence against the original identity that is Antoinette. Such a move would be based on actual difference. Rather, these developments express Rhys's repeated presentation of becoming, expressed not from the point of view of a pre-determined, original identity against which these becomings are judged as good or bad, but as constitutive of Antoinette's identity itself.

Such an approach is necessary for any Deleuzian reading of Wide Sargasso Sea given his claim that repetition 'is not underneath the masks, but is formed from one mask to another' (Deleuze 2004: 19). Here Deleuze characterises identity as an always-changing series of becomings, a process, Williams explains, akin to death: 'as we become, we die as this particular self and we move towards a final death. But there is something revivifying in the expression of becomings, they make a 
life that must end in death one that participates in intensities' (Williams 2003: 9). In a very clear way, by presenting us with a series of becomings that will end in Antoinette's becoming-Bertha and her suicide, Rhys shows us the inevitable decline towards death as Antoinette Cosway becomes Mason becomes Rochester. The reader witnesses the death of a number of Antoinette's 'selves', but in line with Williams's reading of Difference and Repetition, remains aware of the 'revivifying' potential inherent in that process. Antoinette's declaration of her new Mason patronymic, embroidered in vivid red - 'I will write my name in fire red, Antoinette Mason, née Cosway, Mount Calvary Convent, Spanish Town, Jamaica, 1839' (44) - records the passing of her previous self (Antoinette Cosway) and stands as a positive assertion of a new identity, a point Simpson touches upon when she argues that in writing her name Antoinette 'creates a bold, fire-red marker of her life that very much contrasts with the attempts at erasure on the part of those who surround her' (Simpson 2005: 126). Although not consciously pursuing a Deleuzian reading of Rhys's novel, here Simpson identifies the central drive of the novel as the tension between a process of becoming that renews the life of the protagonist and one which leads to her pre-determined fate.

Antoinette's other masks or becomings similarly expose such a tension. The parallel established between Antoinette and her childhood friend Tia, who appears as a mirror image of the protagonist on the night of the burning of Coulibri - 'we stared at each other, blood on my face, tears on hers. It was as if I saw myself. Like in a looking-glass' (38) - is recalled (repeated) at the end of the novel to offer a sense of how things might have been very different for Antoinette. Tia, as Antoinette's double, is, in Part Three of the novel when she appears in Antoinette's dream, a virtual side or, more precisely, a potential differentiation of Antoinette's character: a sign of one self she might have become if it were not for the factors of economic tension, racial difference and social discontent (all intensities expressed in relation to the experience of Emancipation in Jamaica), which led Antoinette's becomings in a specific direction, towards becoming-Bertha. The same is true of another double, the picture of 'The Miller's Daughter', which Antoinette attempts to mirror. In doing so she hopes to become more like the image of English virtue she believes her husband desires in a wife. Yet again, this projected new self does not allow Antoinette to become like 'a lovely English girl' (30), because of her relation to another set of intensities and becomings. Antoinette, like her mother, is 'so without a doubt not English' (30), and her creole heritage evokes for Rochester a different set of becomings that express degeneracy, madness and an illicit sexuality. As a result, her 
attempt to become-English is overwhelmed by the forces that repeat the processes of Brontë's novel as becoming-Bertha.

One of the most commented upon aspects of Wide Sargasso Sea, besides that of its association with Jane Eyre, is the novel's exploration of the mother/daughter relationship. Critics such as Ronnie Scharfman employ the developmental psychology of Nancy Chodorow and D. W. Winnicot in order to read Rhys's novel as 'the narrative of a subject's painful inability to constitute itself as an autonomous identity, to belong' (Scharfman 1981: 99-100). ${ }^{8}$ Following Winnicott's claim that what a baby sees in his/her mother's face is him or herself, Scharfman argues that Antoinette projects a fragmented identity because as a child she did not experience her mother as a mirror. However, rather than reading Antoinette's narrative, as Scharfman does, as the account of an original identity that then becomes fragmented throughout the course of the novel, a Deleuzian approach suggests that Rhys presents a series of inevitable becomings that co-exist alongside a range of virtual ways in which Antoinette could possibly become. These alternative possibilities are presented to the reader in the mirror images and doubles that exist within the novel not only as virtual lines of becoming that Antoinette might have followed, but in themselves as actual differentiations that cannot be mirrored or repeated: as difference. Deleuze, Williams argues, paints a similar picture:

reflections, doubles, soul sisters and brothers, acts of celebration and commemoration are all cases where the repetition or the experience of repetition is accompanied by intense reactions allied to the persistence of difference. [...] In each case, the emotions are double - something is sensed in the same way but there is also a sensation of a profound difference. (Williams 2003: 32-3)

Just as Rhys's novel contrapuntally differentiates Jane Eyre, Antoinette's doubles offer virtual lines of becoming that coexist with the various ways in which Antoinette 'actually' becomes. Moreover, just as Wide Sargasso Sea as the repeated double of Jane Eyre illustrates 'the persistence of difference', the fact that in every repetition the only likeness is difference or the power to become, so Antoinette's doubles evoke the dual sense of similarity and difference. For Antoinette, Tia is her mirror image 'it was as if I saw myself. Like in a looking-glass' (38) - but also a sign of their irreducible difference. 'The Miller's Daughter' is the image of Antoinette's future self and the marker of her unsettling creole difference that Rochester will never manage to accommodate. For Rhys, as for 
Deleuze, the repetition evident in reflections, mirror images and doubles echo only the forward movement of becoming and the impossibility of any other form of repetition. The self cannot become its double or mirror image, it can only become: 'I remember watching myself brush my hair and how my eyes looked back at me. The girl I saw was my self yet not quite myself. Long ago when I was a child and very lonely I tired to kiss her. But the glass was between us - hard, cold, and misted over with my breath' (147). It is this persistent separation, the repetition of difference rather than the same that Wide Sargasso Sea evokes in its presentation of Antoinette's reflected image.

Antoinette's mirror image evokes the double emotion that Williams recognises in Difference and Repetition: almost herself, but not quite. Instead of unity, separation persists, and a similar process emerges in Antoinette's relationship with her mother. In line with Winnicott, Antoinette does, initially, approach her mother's face as a potential mirror. But rather than never seeing herself reflected in her mother, as Scharfman argues, Antoinette encounters in her mother a series of becomings (becoming-disillusioned, becoming-unstable) that she is expected to mirror. The most striking example of this is offered in the repeated image of Annette's frown, 'deep - it might have been cut with a knife' (17), in Antoinette. As Rochester later observes of his wife, 'I looked at the sad droop of her lips, the frown between her thick eyebrows, deep as if it had been cut with a knife' (114). This apparent realisation of the mother mirror image is enforced once again by the novel's ending, in which Antoinette's appearance as the madwoman surrounded by the flames of the burning estate house is a repetition of her mother's fate: 'I went into the hall again with the tall candle in my hand. It was then that I saw her - the ghost. The woman standing with streaming hair. She was surrounded by a gilt frame but I knew her' (154). Here Antoinette becomes both her mothers, Annette and Bertha, signifying for critics such as Scharfman a 'long-desired, long-delayed mirroring fusion' with the mother that gives Antoinette a 'paradoxical freedom through death' (Scharfman 1981: 104). ${ }^{9}$ What such a reading ignores, however, is the way in which the ending represents a culmination of forces that have coerced Antoinette to mirror those aspects of her mother that she does not identify with, her pain and her madness: 'I hated this frown and once I touched her forehead trying to smooth it'; 'after I knew that she talked aloud to herself I was a little afraid of her' (17). Looking beyond the actual repetition of images which recall the mother figure - the barefooted woman, the burning house, the secluded madwoman - Rhys's novel depicts a process of becoming that 
is stunted by being coerced (by expectation and habit) into a repetition of the same rather than difference.

Mirror images and doubles are discrepant throughout Wide Sargasso Sea because, as a repetition itself, Rhys's novel draws attention to the fact that there is no possible 'mirroring fusion' only, to use the Deleuzian formula, the eternal return of difference. Characters such as Rochester who fail to recognise the difference in repetition, who see in repetition only the recurrence of the same or the general and find in Antoinette only the recurring image of the madwoman in the attic that is her mother/Bertha, fail to realise the potential for re-dress in the virtual aspect of Brontë's novel. In this respect, he becomes the Rochester of Jane Eyre who claims 'Bertha Mason is mad and she came of a mad family. [...] Bertha, like a dutiful child, copied her parents' (Brontë 1990: 298). It is the fate of Antoinette's other mother, Bertha, that warns the reader against celebrating too readily any union with the mother, for she is precisely the image of creole madness that Rhys sought to deconstruct. Rhys is not the 'dutiful child' copying the mother text; rather Wide Sargasso Sea is a difficult double, a 'repetition-withdifference' (Harrison 1988: 135) as Nancy Harrison observes. It is an account of Antoinette's becoming-Bertha that continually repeats her difference (her becoming).

Rather than reading in Antoinette's alienation from her mother a sign of her fragmented psyche, the model of becoming that I have used to discuss Rhys's novel offers an understanding of identity as a series of masks. In turn, as Williams explains with respect to Deleuze, this demands a new approach to psychoanalysis based not on the validation of actual events or the recovery of an original trauma, but rather "analysis "works" because roles and masks are authenticated. [...] It is a site where a way of creating other masks is given a seal of approval' (Williams 2003: 49). If we may be empowered by the authentication of our masks, then the converse also holds true: masks which are rejected creates alienation. This, I would argue, is precisely the trauma that Antoinette suffers. Her attempt to validate her identity as Antoinette Mason by embroidering it in fire red, her attempt to take on the role of the Miller's Daughter, her childhood mirror image in Tia, these all stand as masks (becomings) that are never authenticated. Her marriage to Rochester, his fixation on her sexuality and heritage, and the racial tensions of post-Emancipation Jamaica, these factors deny Antoinette's masks the approval she seeks. Instead, those masks which offer Antoinette the least degree of freedom are the ones that are approved: her becoming-Annette, becoming-Bertha. Thus, what the 
reader witnesses is a series of becomings or masks, some of which are validated, some of which are not, and it is in the rejection of certain masks, forcing Antoinette to become like what she would have to be like to deserve her fate, that the greatest violence lies.

It is the denial of the significance of the virtual past, the ability to become in unforeseen ways, that Rhys most directly seeks to challenge in Wide Sargasso Sea. As a repetition itself, Rhys's novel differentiates Jane Eyre by actualising the series of becomings that lead up to the burning of Thornfield Hall. What results is new, drawn from the virtual aspect of the canon, repeating its difference. Rhys's open ending which only suggests that Antoinette finally enacts Bertha's role again exposes the expectancy of the reader and the desire to find in repetition the perfect mirror image: 'at last I know why I was brought here and what I have to do. There must have been a draught for the flame flickered and I thought it was out. But I shielded it with my hand and it burned up again to light me along the dark passage' (155-6). Although this moment is a repetition of Brontë's novel, it is not an actual repetition: it takes us behind the closed doors and 'dark passage[s]' of Thornfield Hall that cannot be accessed by Jane Eyre. As a result, Rhys's ending remains alive with the potential to become a very different story - the flame might go out, Antoinette might not follow the fate of Bertha foretold in her dream and in the life of her mother. Such a virtual possibility critics like Graham Huggan have identified in the novel's resolution: 'should we take Rhys's Antoinette for Brontë's Bertha, and interpret the ending of Wide Sargasso Sea accordingly as the prelude to an inevitable act of self-sacrifice? Or should we listen again to the resurrected Creole parrot? "Ché Coco, Ché Coco". Answering back, cheekily, to Her Mistress's Voice' (Huggan 1994: 657). It is in the discrepancy of repetition that Rhys's novel opens up to the virtual potential of Antoinette's narrative, foregrounding a series of becomings that, in illustrating how the protagonist becomes-Bertha, draws attention to the myriad ways in which things could have been very different.

The Deleuzian framework that this article has traced provides the opportunity to reread Rhys's postcolonial 'writing back' as an illustration of difference as well as repetition: challenging the reader's expectancy and presenting its own becoming-new through a differentiation of the virtual text of Brontë's novel. In the final analysis, Antoinette's claim that 'there are always two deaths, the real one and the one people know about' (106) not only prepares the reader for another death besides her suicide at Thornfield Hall (the death people know about), but displays a sensitivity towards understanding being as a series of becomings 
and deaths. Like her mother whose 'death' she witnesses at the burning of Coulibri, Antoinette dies as one particular self as she becomes another: 'like when he wouldn't call me Antoinette, and I saw Antoinette drifting out of the window with her scents, her pretty clothes and her looking-glass' (147). Rhys's presentation of Antoinette's two deaths, 'two at least' (106), then, finds resonance with Deleuze's claim that 'every death is double', and that 'suicide is an attempt to make the two incommensurable faces coincide or correspond. However, the two sides do not meet, and every death remains double' (Deleuze 2004: 322-3). Bertha's suicide leaping from the rooftop of a blazing Thornfield Hall is discontinuous with Antoinette's inevitable, actual death. The impossibility of bringing together the two sides of death - the death of Antoinette as she becomes-Bertha and her actual suicide - is underscored by Rhys's omission of the anticipated death scene. Her suicide remains outside the bounds of Wide Sargasso Sea, for although Antoinette's becomingBertha brings her one step closer to her inevitable end, it is a death that Rhys leaves resolutely double, existing virtually in her own novel, only to be realised 'later' in Jane Eyre as the continuation of Bertha's story.

\section{Notes}

1. Despite Hallward's employment of Deleuze to demonstrate the self-defeating aims of postcolonialism, his distinction between a counter-colonial stance that is locked into a fixed dialogue between coloniser and coloniser and an alternative view that holds that 'any creative expression is irreducibly specific to (though not specified by) the situation of its articulation' (Hallward 2001: 62), is one which I adapt to delineate the postcolonial project. For further analysis of Hallward's problematic reading of postcolonialism, see Burns (2009).

2. As Sartre writes, 'the oppressors produce and maintain by force the evils that render the oppressed, in their eyes, more and more like what they would have to be like to deserve their fate' (Sartre 1974: xxvi).

3. Mardorossian also notes the parallel between Antoinette's dress slipping off one shoulder and the depiction of the Miller's Daughter (Mardorossian 1999: 1076).

4. Stuart Hampshire's Spinoza and Spinozism provides a lucid outline of Spinoza's single-substance philosophy. For further discussion of Spinoza's philosophy in a postcolonial context, see Burns (2009).

5. Jay Lampert similarly implies this sense of archiving in his description of the second synthesis as 'a "storehouse" of temporal moments' (Lampert 2006: 41). If the 'flaw in [this] metaphor is that it suggests inert memory packages' (41), then Williams's evocation of the Foucauldian/Derridean archive better underscores the creative force of the second synthesis. See, for example, Derrida's claim that 'the archive [...] is not only the place for stocking and for conserving an archivable content of the past which would exist in any case, as such, without the archive. [...] No, the technical structure of the archiving archive also determines the structure of the archivable content even in 
its very coming into existence and in its relationship to the future. The activation produces as much as it records the event' (Derrida 1995: 17). Foucault's archive is similarly creative, particularly as that which drives the production of the new as differentiation: 'its threshold of existence is established by the break that separates us from what we can no longer say, and from what falls outside our discursive practice. [...] It causes the other and the outside to burst forth' (Foucault 1972: 130-1).

6. Colebrook's brief analysis of Wide Sargasso Sea remains one of the few Deleuzian readings of Rhys's work. In another Deleuzian reading, Carol Dell'Amico draws on Deleuze's account of masochism in Coldness and Cruelty in order to reread Rhys's early texts as expressions of a subversive female empowerment (Dell'Amico 2005: 57-95). The main body of recent criticism on Wide Sargasso Sea, however, has focused on Antoinette's ambivalent creoleness as the primary site of resistance to colonial/patriarchical orders (see Alcocer 2005: 160-6; Huggan 1994; Mardorossian 1999; Murdoch 2003; Simpson 2005: 111-15, 136).

7. Kloepfer's study presents an analysis of the specific repetitions of Jane Eyre in Rhys's novel, such as parallels between Jane and Antoinette's dreams (Kloepfer 1989: 154).

8. For further discussion of the mother/daughter relationship in Rhys's work, see Gunner (1994: 136-51), Simpson (2005: 8-16, 115-21), O’Connor (1986: 171-96), Kloepfer (1989: 142-58).

9. Following Scharfman, Klopfer and Gunner have similarly viewed the mother connection as empowering, allowing Antoinette to narrate her story (Kloepfer 1989: 147-8); or to challenge patriarchy (Gunner 1994: 143).

\section{References}

Alcocer, Rudyard (2005) Discourses of Heredity and Caribbean Literature, London and New York: Routledge.

Ashcroft, Bill, Gareth Griffiths and Helen Tiffin (2002) The Empire Writes Back: Theory and Practice in Post-Colonial Literatures, London: Routledge.

Bernabé, Jean, Patrick Chamoiseau and Raphaël Confiant (1993) Éloge de la créolité, trans. M. Taleb-Khyar, Paris: Gallimard.

Bhabha, Homi (1994) The Location of Culture, London: Routledge.

Brontë, Charlotte (1990) Jane Eyre, London: Virago Press.

Burns, Lorna (2009) 'Becoming-Postcolonial, Becoming-Caribbean: Édouard Glissant and the Poetics of Creolisation', Textual Practice, 23:1, pp. 99-117.

Colebrook, Claire (2002) Gilles Deleuze, London: Routledge.

Deleuze, Gilles (1991) Bergsonism, trans. Hugh Tomlinson, New York: Zone Books.

Deleuze, Gilles (2004) Difference and Repetition, trans. Paul Patton, London: Continuum.

Dell'Amico, Carol (2005) Colonialism and the Modernist Moment in the Early Novels of Jean Rhys, Routledge: London.

Derrida, Jacques (1995) 'Archive Fever: A Freudian Impression', trans. Eric Prenowitz, Diacritics, 25:2, pp. 9-36.

Foucault, Michel (1972) Archaeology of Knowledge, trans. A. Sheridan Smith, New York: Tavistock Publications.

Glissant, Édouard (1999) Caribbean Discourse: Selected Essays, trans. J. Michael Dash, Charlottesville: University Press of Virginia.

Gunner, Liz (1994) 'Mothers, Daughters and Madness in Works by Four Women Writers', Alif: Journal of Comparative Poetics, 14, pp. 136-51. 
Hallward, Peter (2001) Absolutely Postcolonial: Writing Between the Singular and the Specific, Manchester: Manchester University Press.

Hampshire, Stuart (2005) Spinoza and Spinozism, Oxford: Claredon Press.

Hardt, Michael (1993) Gilles Deleuze: An Apprenticeship in Philosophy, London: UCL Press.

Harris, Wilson (1983) The Womb of Space, London: Greenwood Press.

Harris, Wilson (1996) Jonestown, London: Faber and Faber.

Harrison, Nancy (1988) Jean Rhys and the Novel as Women's Text, London: University of North Carolina Press.

Huggan, Graham (1994) 'A Tale of Two Parrots: Walcott, Rhys, and the Uses of Colonial Mimicry', Contemporary Literature, 35:4, pp. 643-60.

Kloepfer, Deborah (1989) The Unspeakable Mother: Forbidden Discourse in Jean Rhys and H. D., Ithaca: Cornell University Press.

Lampert, Jay (2006) Deleuze and Guattari's Philosophy of History, London: Continuum.

Mardorossian, Carine (1999) 'Shutting up the Subaltern: Silences, Stereotypes, and Double-Entendre in Rhys’s Wide Sargasso Sea', Callaloo, 22:4, pp. 1071-90.

Memmi, Albert (1974) The Coloniser and the Colonised, trans. Howard Greenfield, London: Souvenir Press.

Murdoch, H. Adlai (2003) 'Rhys's Pieces: Unhomliness as Arbiter of Caribbean Creolisation', Callaloo, 26:1, pp. 252-72.

O'Connor, Teresa (1986) Jean Rhys and the West Indian Novels, New York: New York University Press.

Raiskin, Judith (1996) Snow on the Canefields: Women's Writing and Creole Subjectivity, Minneapolis: University of Minnesota Press.

Rhys, Jean (2000) Wide Sargasso Sea, London: Penguin Books.

Said, Edward (1993) Culture and Imperialism, London: Chatto and Windus.

Sartre, Jean Paul (1974) 'Introduction', The Coloniser and the Colonised, Albert Memmi, trans. Howard Greenfield, London: Souvenir Press.

Scharfman, Ronnie (1981) 'Mirroring and Mothering in Schwartz-Bart's Pluie et vent sur Télumée Miracle and Rhys’s Wide Sargasso Sea', Yale French Studies, 62, pp. 88-106.

Simpson, Anne (2005) Territories of the Psyche: The Fiction of Jean Rhys, Basingstoke: Macmillan.

Smith, Daniel (2007) 'The Conditions of the New', Deleuze Studies, 1:1, pp. 1-21.

Soyinka, Wole (1976) Myth, Literature and the African World, Cambridge: Cambridge University Press.

Walcott, Derek (1998) What the Twilight Says, New York: Farrar, Straus and Giroux.

Williams, James (2003) Gilles Deleuze's Difference and Repetition, Edinburgh: Edinburgh University Press. 